\title{
Lack of Relatedness of Legionella pneumophila to Cytophagaceae, "Pasteurellaceae," and Kingella
}

\author{
DON J. BRENNER, ${ }^{1}$ ARNOLD G. STEIGERWALT, ${ }^{1}$ SABINE POHL, ${ }^{2}$ HELMUT BEHRENS, ${ }^{3}$ WALTER \\ MANNHEIM, ${ }^{2}$ AND ROBERT E. WEAVER ${ }^{4}$
}

Enteric Section ${ }^{1}$ and Special Bacteriology Section, ${ }^{4}$ Division of Bacteriology, Centers for Disease Control, Public Health Service, U.S. Department of Health, Education and Welfare, Atlanta, Georgia 30333, and Hygiene-Institut der Philipps-Universität, D-3550 Marburg/Lahn, ${ }^{2}$ and Gesellschaft für Biotechnologische Forschung, D-3300 Braunschweig-Stöckheim, ${ }^{3}$ Federal Republic of Germany

Deoxyribonucleic acid from Legionella pneumophila showed little or no relatedness to deoxyribonucleic acids from members of the families Cytophagaceae and "Pasteurellaceae" (not on Approved Lists of Bacterial Names [Skerman et al., ed., Int. J. Syst. Bacteriol. 30:225-420, 1980]) or from Kingella kingae. These data support the recent recognition of $L$. pneumophila as a new species.

The Legionnaires disease bacterium was recently named Legionella pneumophila and placed in the new family Legionellaceae (2). The investigators stated that it was impossible to prove that $L$. pneumophila is different from all described species at the levels of species, genus, and family. They listed 15 genera that had guanine-plus-cytosine contents in their deoxyribonucleic acids (DNA) similar to that of $L$. pneumophila and for which possible relatedness to L. pneumophila had not been tested (2). In the present study we tested deoxyribonucleic acid (DNA) relatedness between $L$. pneumophila and species of Cytophagaceae and "Pasteurellaceae" (not on Approved Lists of Bacterial Names [5]) and Kingella kingae.

The strains used in this study are listed in Table 1. Detailed information on the L. pneumophila strains $(2,3)$, the strains of "Pasteurellaceae" (S. Pohl, Ph.D. thesis, Phillips-Universität, Marburg, Federal Republic of Germany, 1979), and the strains of Cytophagaceae ( $\mathrm{H}$. Behrens, Ph.D., thesis, Technischen Universität Carolo-Wilhelmina zu Baunschweig, Brunswick, Federal Republic of Germany, 1978) has been published. K. kingae CDC 5530, a human blood isolate from California, was received in the Special Bacteriology Section at the Centers for Disease Control in 1960. Methods for the cultivation of the bacteria, the preparation of both tritiated DNA and unlabeled DNA, and the hydroxyapatite assay for DNA relatedness have all been described (1-3; Behrens, Ph.D. thesis; Pohl, Ph.D. thesis).

DNA relatedness results obtained with tritiated DNA from L. pneumophila strain Philadelphia 1, the type strain, are shown in Table 1. L. pneumophila strains Albuquerque 1 and Pontiac 1 were $90 \%$ related to strain Philadelphia 1 in $60^{\circ} \mathrm{C}$ reactions. They were $77 \%$ related to Philadelphia 1 in $75^{\circ} \mathrm{C}$ reactions, in which only closely related nucleotide sequences (less than 5\% noncomplementary bases) can reassociate. All species of "Pasteurellaceae" and Cytophagaceae tested were unrelated to $L$. pneumophila.

Behrens (Ph.D. thesis) has recently studied DNA relatedness among Cytophagaceae, and Pohl (Ph.D. thesis) studied DNA relatedness among "Pasteurellaceae." The strains of Cytophagaceae and "Pasteurellaceae" used in the present study were chosen to represent the different hybridization groups demonstrated by the work of Behrens and of Pohl (Ph.D. theses). Collectively, these strains are $20 \%$ or more related to most, if not all, described species within these families. We are therefore confident that the lack of relatedness between $L$. pneumophila and the species tested provides a firm basis for concluding that $L$. pneumophila is not related to either Cytophagaceae or "Pasteurellaceae."

In $60^{\circ} \mathrm{C}$ reactions, $L$. pneumophila DNA showed $17 \%$ reassociation with DNA from $K$. kingae. At $75^{\circ} \mathrm{C}$, these DNAs showed $2 \%$ reaction. This level of relatedness is reproducible and, although low, is higher than that observed between $L$. pneumophila and any other species tested here or previously $(2,3)$. Taken literally, 15 to $20 \%$ relatedness certainly indicates different species, and, at least genetically, different genera. This level of relatedness is, however, frequently observed in reactions between strains from different genera within the same family.

We tend to discount the significance of this low level of reassociation between $L$. pneumophila and $K$. kingae for the following reasons. L. pneumophila DNA was labeled in vitro. We have experienced occasional difficulties with nonspecific reassociation in in vitro-labeled DNA (D. J. Brenner, unpublished data). The thermal stability of double-stranded sequences formed between DNAs that are 15 to $25 \%$ related 
TABLE 1. Relatedness of DNA from L. pneumophila strain Philadelphia 1 to DNAs from K. kingae and strains of species in Cytophagaceae and "Pasteurellaceae"

\begin{tabular}{|c|c|c|}
\hline \multirow{2}{*}{ Bacterial source of unlabeled DNA ${ }^{a}$} & \multicolumn{2}{|c|}{$\begin{array}{c}\text { \% Relatedness with labeled } L \text {. pneumophila } \\
\text { Philadelphia 1 DNA } \\
\end{array}$} \\
\hline & $60^{\circ} \mathrm{C}$ & $75^{\circ} \mathrm{C}$ \\
\hline Legionella pneumophila Philadelphia 1 & 100 & 100 \\
\hline L. pneumophila Albuquerque 1 & 90 & 77 \\
\hline L. pneumophila Pontiac 1 & 89 & 77 \\
\hline Kingella kingae CDC 5530 & 17 & 2 \\
\hline Pasteurella haemolytica NCTC 9380 & 0 & \\
\hline "P.piscicida" ATCC 17911 & 0 & \\
\hline P. multocida NCTC 3195 & 1 & \\
\hline "P. bettii" NCTC 10535 & 1 & \\
\hline Pasteurella sp. NCTC 10699 & 0 & \\
\hline Pasteurella sp., BL group, NCTC 10547 & 2 & \\
\hline "Actinobacillus seminis" ATCC 15768 & 0 & \\
\hline A. equuli NCTC 3365 & 0 & \\
\hline A. actinomycetemcomitans NCTC 9710 & 1 & \\
\hline Haemophilus influenzae NCTC 8467 & 1 & \\
\hline H. paragallinarum NCTC $3438^{c}$ & 1 & \\
\hline H. parahaemolyticus NCTC 8479 & 0 & \\
\hline H. paraphrophilus NCTC 10557 & 1 & \\
\hline Cytophaga sp. CYPE & 0 & \\
\hline Cytophaga sp. CYH3 & 0 & \\
\hline Cytophaga sp. FK17 & 0 & \\
\hline Cytophaga sp. $\mathrm{H} 72$ & 0 & \\
\hline Cytophaga sp. H106 & 0 & \\
\hline
\end{tabular}

${ }^{a}$ CDC, Centers for Disease Control; NCTC, National Collection of Type Cultures; ATCC, American Type Culture Collection.

${ }^{b}$ Actual reassociation in homologous L. pneumophila Philadelphia 1 reactions was between 45 and $80 \%$. These were arbitrarily designated $100 \%$, and heterologous values were normalized to them. A control reaction containing only labeled DNA was included in every experiment. The "label only" reaction was between 1 and $7 \%$. Heterologous values were corrected for this background before normalization. All reactions were done at least twice.

" $H$. paravium" according to Hinz and Kunjara (4).

is almost always some 15 to $20^{\circ} \mathrm{C}$ lower than homologous DNA duplexes. Reassociated DNA formed between $L$. pneumophila and $K$. kingae is only 1 to $2^{\circ} \mathrm{C}$ less stable than homologous $L$. pneumophila DNA duplexes. $K$. kingae is culturally and biochemically very different from $L$. pneumophila. All of the following characteristics of $K$. kingae are the opposite of those for $L$. pneumophila: acid production from D-glucose and maltose, growth on blood agar, beta-hemolysis of blood agar, and fermentation in Hugh and Leifson's oxidation-fermentation test.

The results reported here support the recent classification of $L$. pneumophila as a new genus and species.

\section{REPRINT REQUESTS}

Address reprint requests to: Centers for Disease Control, Attention: D. J. Brenner, Enteric Section, 1-B311, Atlanta, GA 30333.

\section{LITERATURE CITED}

1. Brenner, D. J., A. G. Steigerwalt, D. P. Falcão, R. E. Weaver, and G. R. Fanning. 1976. Characterization of Yersinia enterocolitica and Yersinia pseudotuber. culosis by deoxyribonucleic acid hybridization and by biochemical reactions. Int. J. Syst. Bacteriol. 26:180194.

2. Brenner, D. J., A. G. Steigerwalt, and J. E. McDade. 1979. Classification of the Legionnaires' disease bacterium: Legionella pneumophila, genus novum, species nova, of the family Legionellaceae, familia nova. Ann. Intern. Med. 90:656-658.

3. Brenner, D. J., A. G. Steigerwalt, R. E. Weaver, J. E. McDade, J. C. Feeley, and M. Mandel. 1978. Classification of the Legionnaires' disease bacterium: an interim report. Curr. Microbiol. 1:1-75.

4. Hinz, K.-H., and C. Kunjara. 1977. Haemophilus avium, a new species from chickens. Int. J. Syst. Bacteriol. 27: 324-329.

5. Skerman, V. B. D., V. McGowan, and P. H. A. Sneath (ed.). 1980. Approved lists of bacterial names. Int. J. Syst. Bacteriol. 30:225-420. 